\title{
Impact of Gender Inequality on Economic Growth
}

\author{
Parvaneh Salatin, Hamideh Shaaeri \\ Islamic Azad University, Firoozkooh, Iran
}

\begin{abstract}
The main purpose of this paper is to examine the relationship between the theoretical and the impact of gender inequality on economic growth in middle-income selected countries. The results by using the generalized method of moments (GMM) to estimate the middle income selected countries for 1991-2011 period show that the gross enrollment rate in secondary education for women and men as well as men's life expectancy has omitted significant positive impact on economic growth in the middle income selected countries.
\end{abstract}

Keywords: gender inequality, economic growth, generalized method of moments (GMM)

\section{Introduction}

Nowadays, particular attention has been paid to human capital inequality between men and women and the role that this inequality has played in economic growth. In a point of economists' view, inequality is effective on economic growth in human capital through effects on social and health variables, such as life expectancy and infant mortality rates. Boserup (1970), in research about this type well and simply, argued about neglecting the role of women in development programs. In this study, it was stated that omittance on research has been done up to now in relation to matters of economic development, reflecting that the women's issues are very poor.

Assessing the status of women in different societies needs to calculate various measures in the fields of scientific, economic, social, and political that calculate these factors and compare them with men of similar items, show the progress and development of countries, and determine their position relative to other countries in the global and regional level. Investment in women's education not only reduces the gender gap, but will promote productivity, higher productivity, and higher income. Educated women play an important role in improving the health and education of their children. Attention to women's empowerment and their impact on economic growth either directly or indirectly emphasized the need for research on the role of women in economic development.

In this context, the main objective of this paper is to study gender inequality on economic growth in middle income selected countries. In this paper, a dynamic panel data model (DPD) is used to test the following hypotheses:

- Women's gross enrollment rate at the secondary level as an indicator of human capital for women has significant positive impact on economic growth in middle-income selected countries;

\footnotetext{
Parvaneh Salatin, M.A., faculty member of Department of Economis, Firoozkooh Branch, Islamic Azad University, Firoozkooh,

Hamideh Shaaeri, student of Department of Economis, Firoozkooh Branch, Islamic Azad University, Firoozkooh, Iran.

Correspondence concerning this article should be addressed to Tahereh Jahani, Rajaai st., Rajaai 25 AV., Katalom, Ramsar, Mazandaran, Iran.
} Iran. 
- Women's life expectancy as an indicator of women's human capital represents a positive and significant impact on economic growth in middle-income selected countries;

- Men's gross enrollment rate at the secondary level as indicator of human capital for men has significant positive impact on economic growth in middle-income selected countries;

- Men's life expectancy as an indicator of men's human capital represents a positive and significant impact on economic growth in middle-income selected countries.

The World Bank (WB) is used for data in the address of www.worldbank.org. In this paper, the middle-income group countries selected are Iran, Turkey, Venezuela, Algeria, Argentina, Azerbaijan, Belarus, Brazil, China, Colombia, Cuba, Ecuador, Jordan, Kazakhstan, Lebanon, Libya, Malaysia, Mexico, Hungary, Peru, Romania, Bulgaria, Thailand, Tunisia, Panama, Namibia, Mauritius, Maqdvnyh, Rica, Dominican Republic, Belize, Botswana, Costa Rica, Masdvnya, South Africa, and the Republic of Gabon. ${ }^{1}$ In the following, after a review of the theoretical and research background, the model will be introduced and it is estimated; and then, the political conclusions and recommendations will be presented.

\section{Theoretical Basics and Reviews}

Although it has long been believed that human capital plays a fundamental role in economic growth, studies based on cross-country data have produced surprisingly mixed results (Barro, 1991; Mankiw, Romer, \& Weil, 1992; Benhabib \& Spiegel, 1994; Islam, 1995; Krueger, 1995; Pritchett, 2001; Temple, 2001).

Many developing countries exhibit considerable gender inequality in health, employment, and education for example, girls and women in South Asia and China suffer from much higher mortality rates than men do - creating what Amartya Sen calls "missing women" (Klasen \& Wink, 2002; Sen, 1989). Employment opportunities and pay also differ greatly by gender in most developing regions (as well as most industrial regions) (United Nations Development Programme [UNDP], 2000; World Bank, 2001). Finally, there are large gender discrepancies in education, particularly in South Asia, the Middle East and North Africa, and Sub-Saharan Africa.

When assessing the importance of these gender inequalities, one has to distinguish between intrinsic and instrumental concerns. If the concern is aggregate well-being - as measured by, for example, Sen's notion of "capabilities" (1999) - then longevity and education should be seen as crucial constituent elements. Given inequality aversion (or, equivalently, declining marginal social valuation of these achievements), gender inequality in these achievements will reduce aggregate well-being.

In addition, one may be concerned about gender equity as a development goal in its own right (apart from its benefits for other development goals) - as recognized by the Convention on the Elimination of All Forms of Discrimination Against Women, which has been signed and ratified by 165 countries (UNDP, 2000). If this is the concern, there is no need to do more than demonstrate inequity in a particular country, which would justify corrective action.

Apart from intrinsic problems of gender inequality, one may be concerned about instrumental effects of gender bias. Gender inequality may undermine a number of development goals. First, gender inequality in education and access to resources may prevent reductions in fertility and child mortality and expansions in education of the next generation. A large literature documents these link ages (Klasen, 1999; Murthi, Guio, \&

\footnotetext{
${ }^{1}$ The population included in this study are a selected group of middle income countries. It should be noted that in choice of the middle income selected countries, countries have been selected for the data variables used in the models studied in this paper for 1991-2011 period which were available.
} 
Drèze, 1995; Summers, 1994; Thomas, 1990; 1997; World Bank, 2001). Thus gender bias in education may generate instrumental problems for development policymakers, as it compromises progress on these other important development goals. Second, gender inequality may reduce economic growth. This issue is important to the extent that economic growth advances well-being (as measured by such indicators as longevity, literacy, and poverty), though not all types of growth do so to the same extent (Dollar \& Kraay, 2000; Drèze \& Sen, 1989; Pritchett \& Summers, 1996; Ravallion, 2001; UNDP, 2000; World Bank, 2001). Thus policies that advance economic growth (and do not impede other development goals) should be of great interest to policymakers.

Theoretical and experimental characterization of economic growth has always been of interest to economists, but due to the effects of gender differences on economic growth, something is new that today by import of humanitarian issues at the development has been of particular interest. In point of view by Sen (2001), gender inequality is classified as inequalities on mortality inequality, fertility inequality, basic facility inequality, special opportunity inequality, professional inequality, ownership inequality, and household inequality. The gender gap in education can be seen as a substantial gender gap on human capital, but is not equivalent, because human capital is not created only by education, but also experience, health, and informal education all play a role in the development of human capital. Hence, on theoretical debate regarding human capital inequality, gender inequality on education may further be mentioned. The importance of education and development of human capital on women and girls is not only the issue on social justice, but gender inequality on human capital is one of the most serious obstacles in the way of economic development; evidence obtained by some authors can attest to this fact.

In fact, gender inequalities lower well-being and are a form of injustice in most conceptions of equity or justice, so that they are problematic both from a well-being and an equity point of view (see among others, Klasen, 2002; 2007).

In another view, more human capital for women due to their efficiency is increased and the rate of female participation in the labor market increases. Human capital is also higher for women which leads to birth rates and infant mortality rates have decreased on society as well as increased life expectancy and age at marriage. Higher education for women leads to increasing the opportunity cost for them to stay at home (McMahon, 1998).

Therefore, more attention should be accorded to human capital and reduced their human capital inequality. Although, the efficiency, equity, and justice are essential on education of discussion learning economy and efficiency and equity may sometimes be in conflict. But it seems that due to the non-market effects of education, it is essential to pay attention to the discussion of inequality, especially gender inequality and to further reduce it to the economic development. Inequality of educational opportunity is always the problem faced with them most countries, especially developing countries. This has had a direct impact on lack of development of countries indirectly and by impacting on non-market variables (social) influence, it also had a negative effect on economic growth of these countries. Recent research indicates which cannot be directly demonstrated by the effect of human capital inequality on economic growth. But also, first it should achieve its effect on variables, such as infant mortality rates or other variables that represent life and hope to the family and society and then measure the impact of mediating variables on economic growth.

Dollar and Gatti (1999) examined the relationship between gender inequality in education and economic growth. They concluded by using data from more than 100 countries, growth in five-year intervals (between 1975 and 1990) that women's education on high school leads to higher growth rates, while the most educated men in this period have led to lower growth rates. But in countries by low education women, the increase on 
women's education has had less effect on economic growth. In countries by high women education, economic growth improved significantly with the increase of women's education. Women's education has a direct impact on income and economic growth. By assuming uniform distribution of natural abilities for boys and girls and that children by higher ability, be taught, gender inequality on education means more opportunities for educated and talented younger boys than girls. As a result, the average natural talent of children educated will be lower than the time when the girls and boys have equal educational opportunities, assuming that human capital is the result of a combination of natural talent and training. Gender inequality on education will lead to decreasing the average of human capital in the economy and thus economic growth slowed down.

Klasen (1999) investigated the effects of gender inequality on economic growth. In this paper, the effect of gender inequalities in section education on long-run economic growth in the East Asia, South Asia, sub-Saharan Africa, and the Middle East on 1960-1992 periods by using panel data regression was evaluated. On this study, gender inequalities education by changing the ratio of women to men in education has been measured. Based on the survey results, the proportion of college-educated women (comparing to educated men) and growth rate of women (comparing to men) has a positive effect on economic growth. Gender inequalities reduce economic growth directly and indirectly by reducing of human capital, the impact of population growth, and the rate of investment.

\section{Materials and Methods}

In this paper, based on the different variables affecting the rate of economic growth to evaluate the impact of gender inequality on economic growth in selected countries, the models (1) and (2) are used:

$$
\begin{aligned}
& \mathrm{LGDP}_{i t}=\beta_{0}+\beta_{1} \mathrm{SEF}_{i t}+\beta_{2} \mathrm{EF}_{i t}+\beta_{3} \mathrm{LOPEN}_{i t}+\beta_{4} \mathrm{LL}_{i t}+\beta_{5} \mathrm{LK}_{i t}+\beta_{6} \mathrm{ICT}_{i t}+U_{i t} \\
& \mathrm{LGDP}_{i t}=\beta_{0}+\beta_{1} \mathrm{SEM}_{i t}+\beta_{2} \mathrm{EM}_{i t}+\beta_{3} \mathrm{LOPEN}_{i t}+\beta_{4} \mathrm{LL}_{i t}+\beta_{5} \mathrm{LK}_{i t}+\beta_{6} \mathrm{ICT}_{i t}+U_{i t}
\end{aligned}
$$

where LGDP is logarithm of gross domestic product (GDP) constant prices in 2005 as an indicator of economic growth; SEF is the gross enrollment rate in secondary school for women; EF is women's life expectancy and EM is men's life expectancy as an indicator of human capital; LOPEM is the logarithm of the ratio of sum exports and imports to GDP as an indicator of the degree of openness; LL represents the logarithm of labor; ${ }^{2}$ LK means the logarithm of real gross domestic fixed capital formation (gross capital formation (constant 2000 US\$)) as an indicator of the physical capital stock; ${ }^{3}$ ICT is the number of telephone lines per 100 people as information and communication technology indicator; $U$ represents the equation error, and $i$ and $t$ are respectively country and time. In this paper, panel unit root tests have been used to examine the results of this test stationary or no stationary for all variables used in Table 1.

In this paper, empirical models are estimated by using generalized method of moments (GMM) estimator and relying on dynamic panel data (DPD) models. GMM estimator, particularly in recent empirical studies of macroeconomic and financial studies has been used widely. Using this method to estimate has many advantages; for example, Beck, Levine, and Loayza (2000) recognized that it is very convenient to use this estimator in order to eliminate the variance of time series data. GMM estimator to estimate the unobserved individual specific effects in model (which is done by inserting the lag of the dependent variable as an explanatory

\footnotetext{
${ }^{2}$ The total workforce includes people with 15 years and older who are referred to the organization business and are seeking work.

${ }^{3}$ The variable of real gross domestic fixed capital formation is used as a substitute for physical capital stock variable.
} 
variable in the model) gives a better control of the endogenous explanatory variables of the model. The results of estimating the equations 1 and 2 by using estimator (GMM) are presented in Table 2.

Table 1

Evaluation of Static and Global Variables Stationary or in Selected Countries

\begin{tabular}{|c|c|c|c|}
\hline \multicolumn{4}{|c|}{ Regression type } \\
\hline Results & $\begin{array}{l}T \text { statistic } \\
(P \text {-value })\end{array}$ & Unit root test & Variables \\
\hline$I_{0}$ & $\begin{array}{l}-10.2458 \\
(0.0000)\end{array}$ & Levin & LGDP \\
\hline$I_{0}$ & $\begin{array}{l}-17.8840 \\
(0.0000)\end{array}$ & Levin & SEF \\
\hline$I_{0}$ & $\begin{array}{l}-10.6247 \\
(0.0000)\end{array}$ & Levin & SEM \\
\hline$I_{0}$ & $\begin{array}{l}-11.9507 \\
(0.0000)\end{array}$ & Levin & $\mathrm{EF}$ \\
\hline$I_{0}$ & $\begin{array}{l}-11.6457 \\
(0.0000)\end{array}$ & Levin & EM \\
\hline$I_{0}$ & $\begin{array}{l}-5.1259 \\
(0.0000)\end{array}$ & Levin & LOPEN \\
\hline$I_{0}$ & $\begin{array}{l}-3.40650 \\
(0.0003)\end{array}$ & Levin & LL \\
\hline$I_{0}$ & $\begin{array}{l}-2.04748 \\
(0.0203)\end{array}$ & Levin & LK \\
\hline$I_{0}$ & $\begin{array}{l}-4.18828 \\
(0.0000)\end{array}$ & Levin & ICT \\
\hline
\end{tabular}

Source: Calculated by EVEIWS.6 software.

Table 2

Results of Estimating the Effect of Human Capital for Male and Female on Economic Growth by Using GMM Method, the Middle-Income Selected Countries

\begin{tabular}{|c|c|c|}
\hline \multirow{4}{*}{ Independent variables } & \multicolumn{2}{|c|}{ Dependent variables } \\
\hline & \multicolumn{2}{|c|}{$\begin{array}{l}\text { Coefficient } \\
\text { (T-statistics) }\end{array}$} \\
\hline & Female: & Male: \\
\hline & Human capital function 1 & Human capital function 2 \\
\hline \multirow{2}{*}{ LGDP(-1) } & $0.671390 * * *$ & $0.443022 * * *$ \\
\hline & $(42.36550)$ & $(9.104258)$ \\
\hline \multirow{2}{*}{ LL } & $0.132282 * * *$ & $0.171582 * * *$ \\
\hline & $(4.641210)$ & $(2.851360)$ \\
\hline \multirow{2}{*}{ LK } & $0.161604 * * *$ & $0.202139 * * *$ \\
\hline & $(18.47940)$ & $(11.49786)$ \\
\hline \multirow{2}{*}{ ICT } & $0.001084 * * *$ & $0.002773 *$ \\
\hline & $(2.948132)$ & $(1.670619)$ \\
\hline \multirow{2}{*}{ LOPEN } & $0.045350 * * *$ & $0.079834 * * *$ \\
\hline & $(7.274051)$ & $(2.881404)$ \\
\hline \multirow{2}{*}{ SEF } & $0.000747 * *$ & 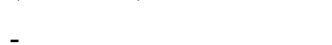 \\
\hline & $(2.077779)$ & \\
\hline SEM & - & $\begin{array}{l}0.002398 * * * \\
(3.928660)\end{array}$ \\
\hline \multirow{2}{*}{ EF } & 0.002570 & \\
\hline & $(1.075281)$ & - \\
\hline \multirow{3}{*}{ EM } & _- & $0.007664 * *$ \\
\hline & - & $(2.033456)$ \\
\hline & 29.1 & 18.1761 \\
\hline
\end{tabular}

Notes. ${ }^{* *}$ significance at $1 \%$ level; $* *$ significance at $5 \%$ level; and $*$ significance at $10 \%$ level. Source: Calculated by EVEIWS.6 software. 


\section{Results}

Results obtained from estimation of equations 1 and 2 in the middle-income selected countries (Table 2) show the following information.

The gross enrollment rate in secondary school for female (SEF) and male (SEM) has positive significant effect on economic growth. In other words, by one percent increase in the gross enrollment rate in secondary school for female (SEF) and male (SEM) on average, economic growth rate $0.000747 \%$ and $0.002398 \%$ increase. By comparing the two estimated model, it can be realized that the gross enrollment rate in secondary education for men has a greater impact on economic growth rate compared to gross enrollment rate in secondary education for female. Furthermore, the life expectancy for women (EF) has no significant effect on economic growth rate. But life expectancy for male (EM) has significant positive effect on economic growth rate. In other words, with one unit rise in life expectancy for men (EM), the average economic growth rate $0.007664 \%$ increases.

In both models, the physical labor (LEL) and physical capital (LK) have significant positive impact on economic growth. Achieving the desired economic growth requires investment. Investment and capital formation are important factors in creating suitable context to increase domestic production which provides greater exports and leads to rising incomes in developing countries. Due to a shortage of investment and the necessity optimized distribution of allocation of resources to stimulate economic growth, it is necessary to identify the comparative advantage of countries in the allocation of investment resources properly. With leading investment resources to the most productive and efficient sector, the efficient use of limited resources will be provided in order to accelerate economic growth. Policies to reduce economic risk, security policies, reduce unnecessary regulations, encourage foreign investment and promot investment opportunities, provid the framework for the prevention of evasion of domestic capital, and lend requirement can be accelerated physical growth of capital and increase its productivity. In both models, the logarithm of the ratio of exports and imports to GDP as an indicator of trade liberalization (LOPEN) has positive significant impact on the rate of economic growth. Export promotion policies by creating division of labor, capacity utilization in the industry, increasing in rate capital formation and technological change, competition in the international market, and leading to higher total factor productivity and economic growth will be higher. Interacting and competing with international markets and improved technology would be used to increase economic growth in the countries. In both models, the number of telephone lines per 100 people as an indicator of information and communication technology (ICT) has positive significant effect on economic growth rate. ICT through total factor productivity growth in manufacturer of ICT sector capital deepening and reorganization could affect the rate of economic growth, another aspect of ICT be increased economic growth; absorbing the high level of investment to the ICT sector, makes new products, and the prices of these products are reduced. ICT has led to the lower opportunity costs which are used in tasks and with creation of added value, reducing in utilization of labor and capital, and accelerating in using the production resources; reducing production costs will lead to the productivity and economic efficiency in production and service.

Also, the Sargan's test statistic (1958), which has distribution with degrees of freedom equal to the number of over-identifying restrictions, rejects the null hypothesis based on correlation between the residuals interdependence and instrumental variables. Based on the results of this testing, instrumental variables used in the estimation models were valid enough. Then, the validity of the results is confirmed for interpretation. 


\section{Conclusions}

Investment in education is a major factor in economic development: whether it is investment in human capital or investment in physical capital. Paying particular attention to the education of the workforce, with the approach to the education of students eligible individuals, the use of university educated, attracting foreign investment, implementation of appropriate fiscal and monetary policies, increased government spending on infrastructure sector, and development of roads and the communication and telecommunication ways are the main strategies for economic development. Regarding the key role of human capital on economic growth, suitable investment in human capital can have good results and can provide suitable education and create an environment for people, especially girls, to create infrastructure in the field of education. It could improve intact human capital. Regarding the research done in this area, it was found that women have a significant role in economic growth as well as it may be important attached to women's role in society, culturally, health, or employment taken great strides to strengthen it.

\section{References}

Barro, R. (1991). Economic growth in a cross section of countries. Quarterly Journal of Economics, 106, 407-443.

Beck, T., Levine, R., \& Loayza, N. (2000). Finance and the sources of growth. Journal of Financial Economics, 58, 261-300.

Benhabib, J., \& Spiegel, M. (1994). The role of human capital in economic development: Evidence from aggregate cross-country data. Journal of Monetary Economics, 34, 143-173.

Boserup, E. (1970). (Reprinted 1997). Women's role in economic development. London: Earth Scan.

Dollar, D., \& Gatti, R. (1999). Gender inequality, income, and growth: Are good times good for women? Washington, D.C.: World Bank Research Department.

Dollar, D., \& Kraay, A. (2000). Growth is good for the poor. Washington, D.C.: World Bank Research Department.

Drèze, J., \& Sen, A. (1989). Hunger and public action. New York: Oxford University Press.

Islam, N. (1995). Growth empirics: A panel data approach. Quarterly Journal of Economics, 110, 1127-1170.

Klasen, S. (1999). Does gender inequality reduce growth and development? Evidence from cross-country regressions. Retrieved from http://siteresources.worldbank.org/INTGENDER/Resources/wp7.pdf

Klasen, S. (2002). Low schooling for girls, slower growth for all? World Bank Economic Review, 16(3), 345-373.

Klasen, S. (2007). Gender-related indicators of well-being. In M. McGillivray (Ed.), Measuring human well-being. London: Palgrave Macmillan.

Klasen, S., \& Wink. C. (2002). A turning point in gender bias in mortality? Population and Development Review, 28(2), $285-312$.

Krueger, A. O. (1995). East Asian experience and endogenous growth theory. In T. Ito and A. O. Krueger (Eds.), Growth theories in light of the East Asian experience (National Bureau of Economic Research-East Asia Seminar on Economics). Chicago: University of Chicago Press.

Mankiw, G. N., Romer, D., \& Weil, D. N. (1992). A contribution to the empirics of economic growth. Quarterly Journal of Economics, 1072, 407-457.

McMahon, W. W. (1998). Education and growth in East Asia. National Magazine, 18(22), 159-172.

Murthi, M. A., Guio, C., \& Drèze, J. (1995). Mortality, fertility, and gender bias in India: A district-level analysis. Population and Development Review, 21(4), 745-782.

Pritchett, L. (2001). Where has all the education gone? World Bank Economic Review, 15(3), 367-391.

Pritchett, L., \& Summers, L. (1996). Wealthier is healthier. Journal of Human Resources, 31(4), 841-868.

Ravallion, M. (2001). Growth, inequality, and poverty: Looking beyond averages. World Development, 29(11), 1803-1816.

Sargan, J. D. (1958). The estimation of economic relationships using instrumental variables. Econometrica, 26(3), 393-415.

Sen, A. (1989). Women's survival as a development problem. Bulletin of the American Academy of Arts and Sciences, 43(2), 14-29.

Sen, A. (1999). Development as freedom. New York: Knopf.

Sen, A. (2001). The many facts of gender inequality. India's National Magazine, 18(22), 466-477.

Summers, L. (1994). Investing in all the people. Washington, D.C.: World Bank. 
Taylor, A. M. (1998). On the costs of inward-looking development. Journal of Economic History, 58(1), 1-28.

Temple, J. (2001). Generalizations that aren't? Evidence on education and growth. European Economic Review, 45(4-6), 905-918. Thomas, D. (1990). Intra household resource allocation: An inferential approach. Journal of Human Resources, 25(4), 634-664.

Thomas, D. (1997). Income, expenditures, and health outcomes: Evidence on intra household resource allocation. In L. Haddad, J.

Hoddinott, and H. Alderman (Eds.), Intra household resource allocation in developing countries: Models, methods, and policy. Baltimore, Md.: Johns Hopkins University Press.

United Nations Development Program [UNDP]. (2000). Human development report. New York: Oxford University Press.

World Bank. (2001). World development report 2000/01: Attacking poverty. New York: Oxford University Press. 